\title{
Analisis Jejaring Sosial Tokoh Publik Menggunakan Metode GrapML
}

\author{
Arief Kurniawan ${ }^{1}$, Aryo Nugroho ${ }^{2}$, Moh. Noor Al Azam ${ }^{3}$ \\ 19arief.kurniawan@mhs.fasilkom.narotama.ac.id, ${ }^{2}$ aryo.nugroho@ fasilkom.narotama.ac.id, \\ ${ }^{3}$ noor.azam@narotama.ac.id
}

Program Studi Sistem Informasi, Universitas Narotama Surabaya

\begin{abstract}
Social Network Analysis (SNA) is a branch of computer science that analyzes phenomena or patterns of relationships on a social network. In this study Twitter is one of the social networking media that will be used as research objects because the number of active users each month reaches more than 330 million and with unlimited access to information. Furthermore, the analytical method used in this study is to use the GraphML method and the calculation of the centrality approach algorithm (Centrality Measure). Where with the GraphML method is able to visualize the relationship of individual social networks with other individuals into a graphical form and can be used to determine the weight of individual ties to other individuals or how strong the relationship of individuals is intertwined. In this analysis the results obtained in the form of a diagram of the degree of centrality with the most dominant actor namely actor 5 with the number of bonds as much as 54, actor 12 with the number of ties as much as 68, actor 12 with the number of ties as much as 30 and on the pagerank diagram the most dominant actor is shown by actor 72,128 , 129, 130, 131, 132, 133.
\end{abstract}

Intisari-Social Network Analysis (SNA) merupakan suatu cabang ilmu komputer yang menganalisis fenomena atau pola hubungan pada suatu jejaring sosial. Pada penelitian ini Twitter merupakan salah satu media jejaring sosial yang akan digunakan sebagai objek penelitian dikarenakan jumlah pengguna aktif setiap bulan yang mencapai 330 juta lebih serta dengan akses informasi yang tak terbatas. Selanjutnya metode analisis yang digunakan pada penelitian ini adalah menggunakan metode GraphML dan perhitungan algoritma pendekatan sentralistas (Centrality Measure). Dimana dengan metode GraphML ini mampu memvisualisasikan hubungan jejaring sosial individu dengan individu lain kedalam bentuk grafik dan mampu digunakan untuk menentukan bobot ikatan indvidu terhadap individu lain atau seberapa kuat hubungan individu tersebut terjalin. Dalam analisis ini diperoleh hasil berupa diagram derajat sentralitas dengan aktor yang paling dominan yakni aktor 5 dengan jumlah ikatan sebanyak 54, aktor 12 dengan jumlah ikatan sebanyak 68, aktor 12 dengan jumlah ikatan sebanyak 30 dan pada diagram pagerank aktor paling dominan di tunjukkan oleh aktor 72, 128, 129, 130, 131, 132, 133.

Kata Kunci-Social Network Analysis; GraphML; Centrality Measure; Twitter

\section{PENDAHULUAN}

Di Indonesia saat ini perkembangan penyampaian informasi melalui jejaring sosial sudah sangat cepat. Selain karena jumlah pengguna yang setiap hari semakin bertambah, kemudahan akses dan fitur pula yang mendorong banyak masyarakat menggunakan fasilitas jejaring sosial saat ini. Jejaring sosial mengacu pada makna hubungan sosial yang dianggap berasal atau diperoleh dengan hubungan antara individu dengan keluarga, tetangga, lingkungan, komunitas dan sebagainya [1], [2]. Tiap individu didalam sebuah jejaring sosial memiliki peran ganda yakni sebagai pusat informasi atau sebagai perantara dalam menyampaikan informasi kepada individu lain [3]. Dalam hubungan jejaring sosial terdapat sebuah wadah atau tempat berkumpul orang-orang dengan kebutuhan, ide atau permasalahan yang sama bertemu untuk saling bertukar pikiran guna mencari solusi terhadap permasalahan yang ada yang sering dinamakan dengan media sosial. Twitter merupakan salah satu perkembangan teknologi media sosial yang memiliki berbagai fungsi dan manfaat dalam kehidupan masyarakat di era digital saat ini. Dengan jumlah fitur yang banyak, Twitter sering kali dijadikan sebagai wadah untuk bertukar informasi antar pengguna baik itu teks, gambar ataupun video. Dengan jumlah 330 juta lebih pengguna aktif tiap bulannya, Twitter menjadi salah satu media sosial pilihan dalam menjalin pertemanan didunia internet [4]. Didalam Twitter pengguna bisa menikmati fitur tweet, yakni membagikan cuitan atau informasi terhadap suatu hal mereka kedalam tulisan yang dibatasi 280 karakter saja. Selanjutnya fitur lain yang bisa dinikmati oleh pengguna Twitter diantara lain yakni keleluasaan membagikan foto, video maupun tautan berita di dalam Twitter kepada temantemannya tanpa adanya batasan-batasan yang berarti.

Didalam jejaring sosial terdapat istilah yang dinamakan tokoh publik. Tokoh publik memilik makna yakni sosok atau seseorang yang dikenal luas oleh masyarakat umum. Di Indonesia tokoh publik lebih cenderung digambarkan sebagai pejabat, pemuka agama, kepala suku, orang-orang dari instansi pemerintahan, artis ataupun penyanyi yang sering muncul di berbagai media digital ataupun surat kabar [5]. Pada penelitian ini penulis memilih tokoh publik dari Nahdlatul Ulama (NU) yakni Nadirsyah Hosen dengan nama akun Twitter@na_dirs [6]. Pria kelahiran 8 Desember 1973 ini merupakan satu-satunya orang Indonesia yang menjadi dosen tetap di Fakultas Hukum Monash University, Melbourne, Australia dan telah mengajar selama 13 tahun disana. Beliau merupakan anak dari Prof. KH. Ibrahim Hosen, seorang ahli fikih kenamaan dan pernah menjabat Ketua 


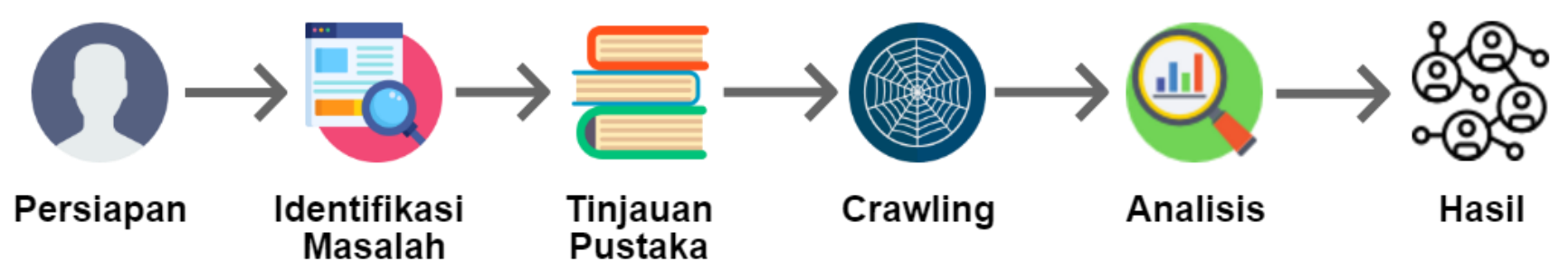

Gambar 1. Langkah-langkah Aktivitas Penelitian

Komisi Fatwa Majelis Ulama Indonesia (MUI) selama dua dekade (1981-2000). Nadirsyah Hosen diketahui telah meraih dua gelar doktor $(\mathrm{PhD}$ in Law dari Universitas Wollongong dan $\mathrm{PhD}$ in Islamic law dari National University of Singapore) dan telah menulis lebih dari 20 artikel di jurnal internasional dan beberapa karya buku berbahasa Indonesia [7]. Beliau merupakan tokoh yang mempunya dua sisi kontras dalam hidupnya, beliau bergaul dalam iklim intelektual ala Barat nan modern. Di sisi lain, beliau tumbuh dalam lingkungan tradisi Islam Nusantara yang mana gelar "GUS" disandangnya sejak lahir karena beliau merupakan keturunan ulama. Kini beliau menjabat sebagai Rais syuriah (pengurus cabang istimewa NU) di Australia dan Selandia Baru. Terkadang beliau pulang ke Indonesia sebagai pembicara dalam suatu acara serta beliau sangat aktif berdakwah di media sosial terutama Twitter [8]. Pada tanggal 18 Maret 2019 Nadirsyah Hosen membuat sebuah cuitan pada Twitter yang sempat mengundang perhatian banyak kalangan. Dimana isi dari cuitan tersebut merupakan bentuk kekecewaan beliau terhadap pembuat meme kedua calon wakil presiden Prof. Dr. (H.C.) K.H. Ma'ruf Amin dan H. Sandiaga Salahuddin Uno, B.B.A., M.B.A. yang mencalonkan pada saat itu. Cuitan tersebut mendapat banyak respon dari banyak pengguna Twitter baik yang merupakan pengikutnya (follower) maupun yang bukan dari pengikutnya.

Dengan adanya latar belakang tersebut, penulis ingin melakukan penelitan mengenai berapa banyak jumlah aktor (node) yang berpengaruh didalam penyampaian informasi dari aktor utama ke aktor lain yang berada didalam jaringan jejaring sosial Twitter milik Nadirsyah Hosen untuk kemudian melakukan visualisasi jaringan menggunakan metode GraphML. Dalam melakukan proses visualisasi GraphML penulis menggunakan algoritma perhitungan dari Analisis Jejaring Sosisal (Social Network Analysis) yakni Pendekatan Sentralitas (Centrality Measure). Pendekatan Sentralitas merupakan metode untuk menghitung jumlah ikatan tiap aktor yang muncul didalam jaringan untuk selanjutnya dilakukan pembobotan yang bertujuan untuk mengetahui berapa jumlah titik pusat selain aktor utama didalam jaringan jejaring sosial tersebut [9].

\section{METODOLOGI PENELITIAN}

\section{A. Langkah-langkah Aktivitas Penelitian}

Pada Gambar 1 menjelaskan tentang langkah-langkah dalam melakukan analisis jejaring sosial tokoh publik dengan metode GraphML diawali dengan mengidentifikasi masalah yang muncul sebagai topik penelitian, kemudian melakukan tinjauan pustaka untuk mencari refrensi penelitian terdahulu dan metode yang akan digunakan. Selanjutnya melakukan crawling yang bertujuan mengambil data dari alamat akun Twitter Nadirsyah Hosen yang telah didapatkan pada saat melakukan tinjauan pustaka, selanjutnya melakukan analisis pembobotan nilai terhadap data yang telah diperoleh, kemudian melakukan visualisasi dari hasil pembobotan yang telah dilakukan.

\section{B. Tinjauan Pustaka}

Terdapat banyak penelitian yang telah dilakukan dalam bidang Analisis Jejaring Sosial, diantaranya adalah penelitian tentang visualisasi jaringan pada jejaring sosial. Sehingga dalam melakukan penelitan, studi pustaka digunakan sebagai salah satu alat dari penerapan metode penelitian. Diantaranya adalah untuk menghindari pembuatan ulang, mengidentifikasi metode yang pernah dilakukan, melanjutkan penelitian yang sebelumnya telah dilakukan, serta mengetahui orang lain yang spesialisasi dan area penelitiannya sama dalam bidang ini. Beberapa studi pustaka diperoleh diantaranya dari jurnal internasional, tesis, buku dan juga sumber lainnya.

\section{Metode Crawling}

Penelitian ini akan melakukan crawling data yang bertujuan untuk mengumpulkan informasi terkait aktor yang terdapat didalam jaringan jejaring sosial Nadirsyah Hosen. Langkah pertama yaitu mengambil alamat URL profil Twitter Nadirsyah Hosen. Selanjutnya melakukan proses ekstraksi URL menggunakan Regular Expresion yang bertujuan mengidentifikasi pola hubungan didalam jaringan. Kemudia tahap akhir dalam proses ini berupa mengekstraksi informasi jumlah aktor dan jumlah ikatan yang dimiliki tiap aktor [10], [11].

\section{Metode Analisis Sentralitas (Centrality Measure)}

Analisis sentralitas merupakan algoritma hitung yang digunakan memberikan nilai indikasi kekuatan sosial suatu node dalam sebuah jaringan jejaring sosial [12]. Analisis dilakukan karena didasari pada pentingnya hubungan aktor atau node yang muncul pada jaringan [13]. Idikasi pentingnya hubungan antar aktor adalah terletak pada dengan siapa aktor terhubung, siapa yang menjadi aktor pusat selain aktor utama, seberapa banyak ikatan yang dibentuk [14]. Untuk menentukan node sentral didalam sebuah jaringan dapat dilakukan dengan dua jenis algoritma Analisis Sentralitas antara lain adalah sebagai berikut. 


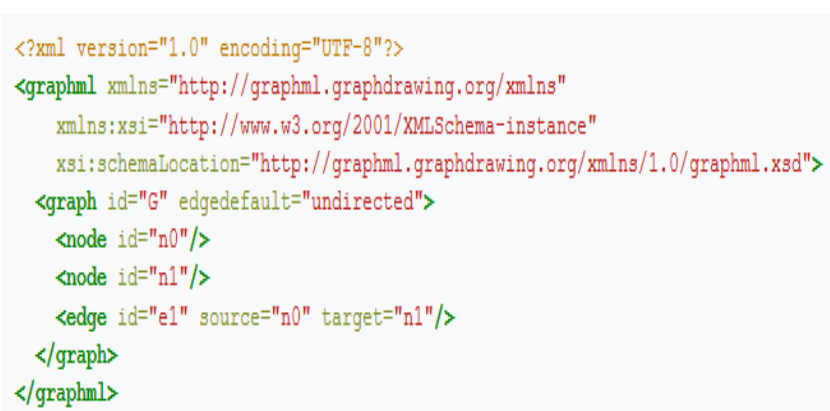

Gambar 1. Kode XML dari GraphML

1) Degree Centrality (DC):Degree Centrality yakni menghitung jumlah koneksi atau interaksi yang dimiliki sebuah node pada jaringan. Hal ini dilakukan untuk mencari tahu berapa jumlah node yang paling berpengaruh didalam jaringan jejaring sosial tersebut selain node utama. Rumus persamaan untuk menghitung Degree Centrality dapat dilihat pada Persamaan (1).

$\mathrm{C}_{D}(i)=\frac{d(i)}{n-1}$

Keterangan :

$C_{D}(i)$ adalah nilai Degree Centrality

$d(i)$ adalah jumlah edge, relasi diantara node

$n$ adalah jumlah seluruh anggota populasi node dalam jaringan

2) Pagerank : Pagerank merupakan suatu pengukuran yang bertolak belakang terhadap peran seorang node jika dibandingkan pengukuran menggunakan Degree Centrality. Pada Pagerank seorang aktor memiliki kedudukan tinggi jika aktor tersebut memiliki ikatan sebagai penerima (in-links) paling banyak didalam jaringan. Perbedaan utama konsep Degree Centrality dan Pagerank adalah Degree Centrality berfokus pada ikatan yang keluar (out-links), sedangkan Pagerank fokus pada ikatan yang masuk (in-links). Dalam mencari Pagerank digunakan rumus persamaan yang dapat dilihat pada Persamaan (2).

$P_{D}(i)=\frac{d(i)}{n-1}$

Keterangan :

$P_{D}(i)$ adalah nilai Pagerank

$d(i)$ adalah jumlah ikatan masuk dari $i$

$n$ adalah jumlah seluruh anggota populasi node dalam jaringan

\section{E. Metode Visualisasi GraphMl}

GraphML (Graph Markup Language) merupakan metode baru untuk membuat sebuah grafik dengan menggunakan bahasa XML (Extensible Markup Language) [15] seperti yang ditunjukan pada Gambar 2. GraphML pada dasarnya memiliki visualisasi layaknya grafik jairngan pada umumnya. Grafik (graph) merupakan bentuk visualisasi hubungan yang muncul akibat adanya ikatan antar aktor satu dengan aktor lain yang

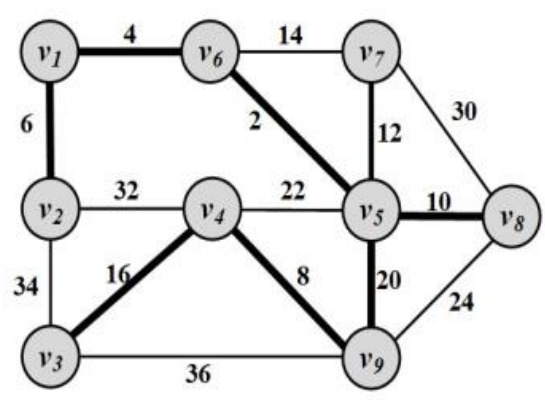

Gambar 3. Subgraf Spanning Tree

disimbolkan dengan node dan edge. Node dikenal juga sebagai simpul yang mewakili aktor atau entitas dan edge adalah busur, atau garis penghubung yang menghubungkan tiap-tiap aktor yang menggambarkan adanya hubungan diantara aktor-aktor tersebut [16]. Sehingga dengan menerapkan metode visualisasi menggunakan GraphML diharapkan menjadi salah satu alternatif dalam menampilkan hubungan jaringan dari analisis jejaring sosial.

Didalam sebuah grafik jejaring sosial terdapat banyak himpunan yang disebut dengan subgraf (subgraph). Dalam teori himpunan, himpunan A dikatakan merupakan himpunan bagian dari B bila hanya setiap anggota A merupakan B. Dari definisi tersebut ada beberapa hal yang dapat diturunkan yakni sebuah titik didalam sebuah garis didalam node A bersamasama dengan titik-titik ujungnya merupakan subgraf A. Dalam subgraf berlaku sifat transitif, misalkan jika $\mathrm{C}$ adalah subgraf B dan B adalah subraf A, maka A adalah subgraf A. Hal ini pula mengacu pada teori subgraf spanning tree yang menjelaskan bahwa subgraf adalah graf terhubung yang dapat disajikan terurut yang mencangkup semua node grafik [17].

Pada Gambar 3 merupakan contoh subgraf spanning tree yang menunjukkan bahwa spanning tree mampu menampilkan semua himpunan yang muncul didalam jaringan hinnga himpunan terkecil yang hanya memiliki satu ikatan didalamnya. Dari grafik tersebut diketahui bahwa V2 merupakan subgraf V1, V1 subgraf V6, kemudian V6, V7 dan V9 adalah subgraf V5, dan V5 adalah subgraf V8.

\section{HASIL DAN PEMBAHASAN}

Dataset pada penelitian ini menggunakan dataset yang diambil dari twitter dengan metode Crawling. Data yang diambil merupakan semua tweet yang terdapat pada akun Nadirsyah Hosen (@na_dirs) dengan metode pencarian data berdasarkan nama akun atau username. Dari data yang telah dikumpulkan dilakukan analisis Degree Centrality $(D C)$ dan Pagerank.

\section{A. Degree Centrality $(\mathrm{DC})$}

Degree Centrality (DC) yakni menghitung berapa banyak ikatan antara sebuah node dengan node lain didalam jaringan. Didalam teori jejaring sosial, indeks ini sering dianggap sebagai ukuran aktivitas aktor. Untuk menghitung DC, digunakan rumus Freeman untuk grafik yang tidak dinilai yang dapat dilihat pada persamaan (1). Hasil dari analisis dapat dilihat pada Tabel 1 


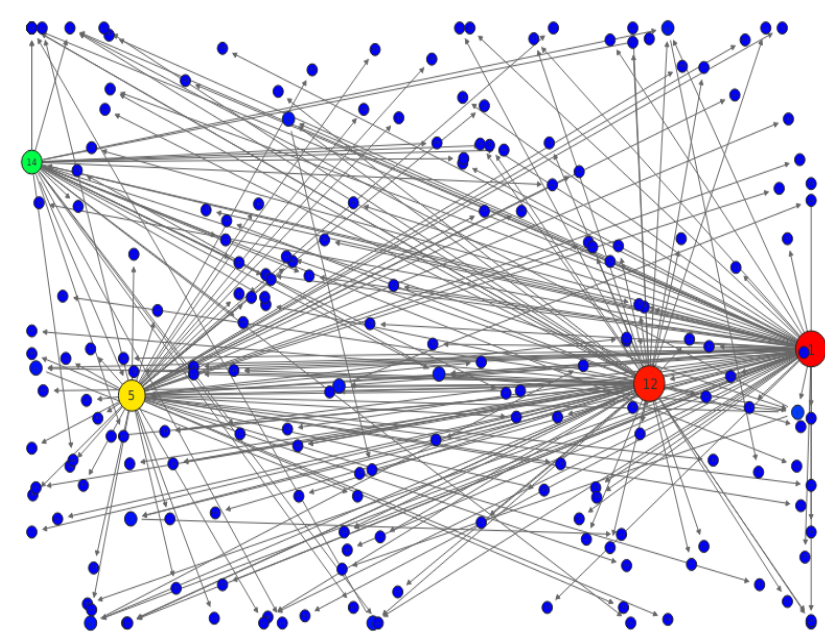

Gambar 4. Grafik hasil pengujian Degree Centrality (DC)

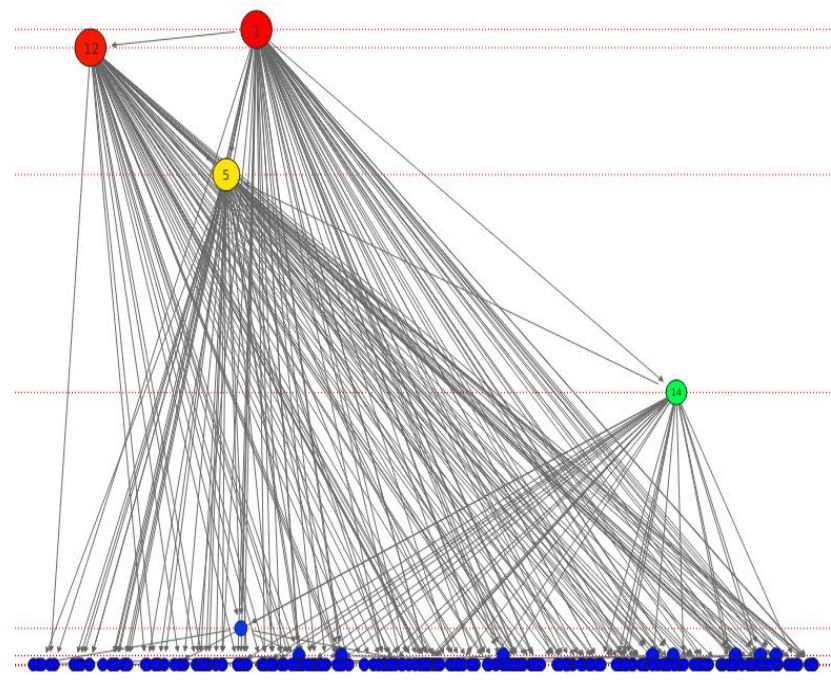

Gambar 5. Visualisasi subgraph berdasarkan bobot Degree Centrality

Tabel 1. Nilai Hasil Pengujian Degree Centrality (DC)

\begin{tabular}{|c|c|c|c|}
\hline Node & Label & DC & DC \\
\hline 1 & https://twitter. & 70.000 .000 & 0.299145 \\
\hline 5 & https://twitter. & 54.000 .000 & 0.230769 \\
\hline 12 & https://twitter. & 68.000 .000 & 0.290598 \\
\hline 14 & https://twitter. & 30.000 .000 & 0.128205 \\
\hline
\end{tabular}

Tabel 2. Nilai Hasil Pengujian Pagerank

\begin{tabular}{|c|c|c|c|}
\hline Node & Label & PRP & PRP \\
\hline 72 & https://about.tw & 0.001564 & 1.000 .000 \\
\hline 128 & https://twitter. & 0.001403 & 0.897082 \\
\hline 129 & https://twitter. & 0.001403 & 0.897082 \\
\hline 130 & https://twitter. & 0.001403 & 0.897082 \\
\hline 131 & https://twitter. & 0.001403 & 0.897082 \\
\hline 132 & https://help.twi & 0.001403 & 0.897082 \\
\hline 133 & http://nadirhose & 0.001422 & 0.908769 \\
\hline
\end{tabular}

Dari Tabel 1 diketahui bahwa pada aktor nomor 5, 12 dan 14 memiliki ikatan terbanyak didalam jaringan tersebut selain aktor utama yakni aktor nomor 1 dengan jumlah ikatan aktor 5 $=54$, aktor $12=68$ dan aktor $14=30$. Selanjutnya dari hasil pengujian yang telah dilakukan dilakukan visualisasi kedalam bentuk GraphMl yang ditunjukkan pada Gambar 4 dan Gambar 5 sebagai berikut.

Pada Gambar 5 ditunjukkan bahwa node sentral selain node utama merupakan node nomor 5, 12, dan 14. Selanjutnya agar memudahkan dalam melakukan pengelompokan untuk mengetahui himpunan yang muncul didalam jaringan digunakan visualisasi subgraf spaning tree yang mengacu pada bobot Degree Centrality yang di tunjukkan pada Gambar 5.

\section{B. Pagerank}

Seorang node dinyatakan memiliki kategori pagerank yakni jika node tersebut menerima banyak ikatan yang masuk kedirinya. Untuk menentukan sebuah node dinyatakan sebagai pagerank atau tidak digunakan rumus persamaan (2). Hasil analisis pagerank dapat dilihat pada Tabel 2.

Dari Tabel 2 di ketahui bahwa aktor dengan nomor 72, 128, 129, 130, 131, 132, dan 133 memiliki nilai paling tinggi yang mengindikasikan bahwa aktor tersebut merupakan aktor pagerank didalam jaringan tersebut. Selanjutnya dari hasil pengujian tersebut dilakukan visualisasi kedalam GraphML yang ditunjukkan pada Gambar 6 dan Gambar 7.

Pada Gambar 6 ditunjukkan bahwa aktor dengan nomor 72, $128,129,130,131,132$, dan 133 dinyakatan sebagai aktor atau node dengan ikatan yang masuk paling banyak didalam jaringan tersebut. Selanjutnya dilakukan pengelompokan himpunan menggunakan subgraph spanning tree yang mengacu pada bobot pagerank yang ditunjukkan pada Gambar 7. 


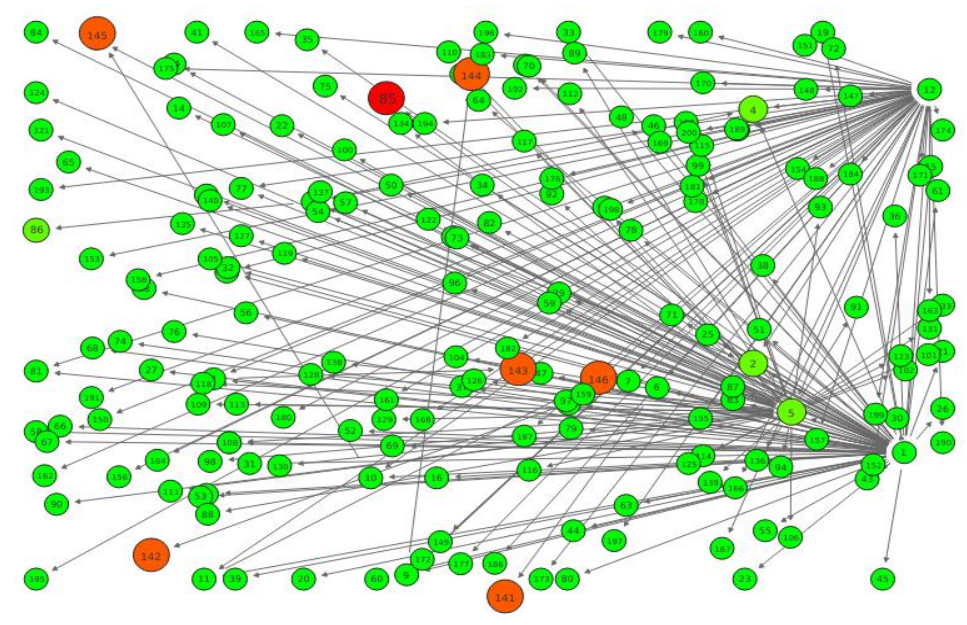

Gambar 2. Grafik hasil Pengujian Pageran

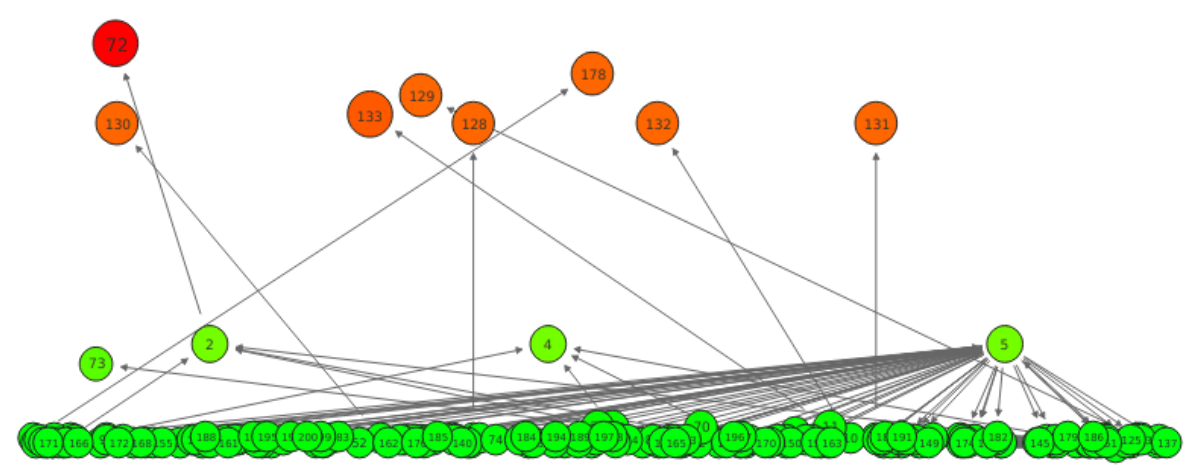

Gambar 3. Visualisasi subgraph berdasarkan bobot Pagerank

\section{KESIMPULAN DAN SARAN}

GraphML dapat digunakan sebagai cara untuk memvisualkan bentuk hubungan jejaring sosial seseorang tertentu salah satunya tokoh publik. Hasil yang di peroleh yakni visualisasi berbentuk Grafik dan Tabel yang berisi nilai jarak hubungan tiap aktor dengan aktor lain didalam jaringan tersebut. Berdasarkan hasil pengujian yang dilakukan didapatkan informasi bahwa dalam menyebarkan informasinya aktor nomor 1 dibantu dengan aktor-aktor lain. Hal ini dibuktikan dengan visualisasi dengan perhitungan Degree Centrality yang menunjukkan bahwa aktor nomor 5, 12 dan 14 menjadi titik sentral dalam grup jaringan kecil. Kemudian dengan perhitungan pagerank interaksi terbanyak ditunjukkan pada aktor dengan nomor 72, 128, 129, 130, 131, 132, dan 133 yang mengindikasikan bahwa node tersebut merupakan orang terdekat dari node utama atau node sentral selain node utama didalam jaringan sosial tersebut.

Data yang di crawling tidak hanya dari satu media sosial twitter saja, bisa melalui facebook, instagram, youtube dan lain-lain. Data hasil crawling mampu menampilkan nama akun aktor yang terdapat dalam jaringan yang divisualisasikan agar lebih mudah mengetahui latar belakang aktor-aktor yang muncul didalam jaringan tersebut. Visualisasi dalam diagram lain yang lebih menarik dan mudah dimengerti oleh pembaca awam.

\section{DAFTAR PUSTAKA}

[1] A. Clifton and G. D. Webster, "An Introduction to Social Network Analysis for Personality and Social Psychologists," Soc. Psychol. Personal. Sci., vol. 8, no. 4, pp. 442-453, 2017.

[2] N. Rosli et al., "VISUALIZATION AND CENTRALITY MEASUREMENT OF SOCIAL NETWORK ANALYSIS," J. Teknol. Univ. Malaysia, vol. 1, pp. 1-6, 2015.

[3] E. B. Santoso and A. Nugroho, "Analisis Sentimen Calon Presiden Indonesia 2019 Berdasarkan Komentar Publik Di Facebook," Eksplora Inform., vol. 9, no. 1, pp. 60-69, 2019.

[4] I. Twitter, "Pertanyaan Umum pengguna baru," 2019. [Online]. Available: https://help.twitter.com/id/newuser-faq. [Accessed: 10-Sep-2019].

[5] U. Hasan, "Publik Figure - Kompasiana.com." [Online]. Available: https://www.kompasiana.com/234/550a64f2813311e1 78b1e193/publik-figure. [Accessed: 05-Nov-2019].

[6] "Profil | Gus Nadirsyah Hosen." [Online]. Available: https://nadirhosen.net/profil. [Accessed: 30-Oct-2019]. [7] H. Yansyah, "Mengenal Prof. Nadirsyah Hosen, Kiai NU yang Juga Dosen Tetap Universitas Monash, Australia Halaman 1 - Kompasiana.com." [Online]. 
Available:

https://www.kompasiana.com/omnduut/5ceb6b0a6b07 c53f0c3ea875/mengenal-prof-. [Accessed: 05-Nov2019].

[8] M. Fikrie, "Nadirsyah Hosen, kisah santri menaklukkan Barat." [Online]. Available: https://beritagar.id/artikel/figur/nadirsyah-hosenkisah-santri-menaklukkan-barat. [Accessed: 05-Nov2019].

[9] G. Boeing, "OSMnx: New methods for acquiring, constructing, analyzing, and visualizing complex street networks," Comput. Environ. Urban Syst., vol. 65, pp. 126-139, 2017.

[10] J. Eka Sembodo, E. Budi Setiawan, and Z. Abdurahman Baizal, "Data Crawling Otomatis pada Twitter," in Indosc 2016, 2016, no. October 2018, pp. $11-16$.

[11] A. Halim et al., "PERANCANGAN APLIKASI WEB CRAWLER UNTUK MENGHASILKAN DOKUMEN TEKS PADA DOMAIN," J. Sist. dan Teknol. Inf., vol. 1, no. 2, pp. 2-5, 2017.

[12] E. Zusrony, H. D. Purnomo, and S. Y. J. Prasetyo, "Analisis Pemetaan Jaringan Komunikasi Karyawan Menggunakan Social Network Analysis pada Perusahaan Multifinance," INTENSIF J. Ilm. Penelit. dan Penerapan Teknol. Sist. Inf., vol. 3, no. 2, p. 145, 2019.

[13] M. J. Kim, H. Ahn, and M. Park, "A GraphML-based visualization framework for workflow-performers' closeness centrality measurements," KSII Trans. Internet Inf. Syst., vol. 9, no. 8, pp. 3216-3230, 2015.

[14] A. I. Sugiarta, D. Syamsuar, and E. S. Negara, "Analisis Sentralitas Aktor pada Struktur Jaringan Politik dengan Menggunakan Metode Social Network Analysis ( SNA ): Studi Kasus Group Facebook Lembaga Survei Sosial Media," in SEMNASTIK, 2018, pp. 1-7.

[15] M. Thangaraj and S. Amutha, "Mgephi: Modified Gephi for Effective Social Network Analysis," Int. J. Sci. Res. Comput. Sci. Eng. Inf. Technol., vol. 1, no. 1, pp. 39-50, 2018.

[16] M. K. A. Bratawisnu Andry, "Social Network Analysis Untuk Analisa Interaksi User Dimedia Sosial Mengenai Bisnis E-Commerce (Studi Kasus: Lazada, Tokopedia Dan Elevenia)," Almana J. Manaj. dan Bisnis, vol. 2, no. Vol 2 No 2 (2018): Vol. 2 No.2/ Agustus 2018, pp. 107-115, 2018.

[17] R. Zafarani, M. A. Abbasi, and H. Liu, Social Media Mining: Graph Essentials. New York, USA: CAMBRIDGE UNIVERSITY, 2014. 